\title{
Management of English Language Learning Process for Children and Adolescent through Distance Learning Program at Homeschooling
}

\section{Musdalifah}

English Education Department, Muhammadiyah University of Enrekang, Indonesia Jalan Jenderal Sudirman No. 17 Enrekang, Sulawesi Selatan 91712, Indonesia Email: musdalifah ifahrahman@yahoo.com

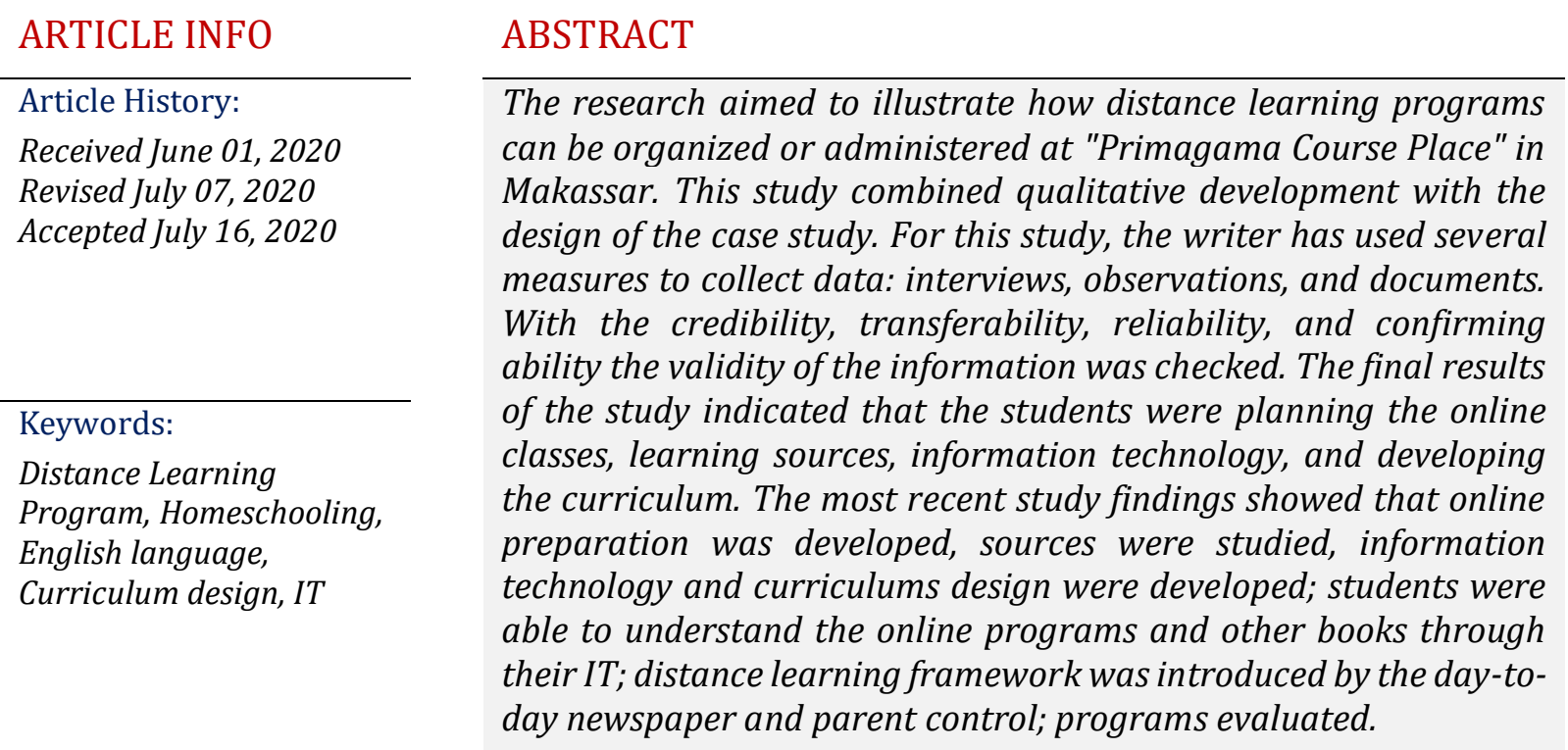

\section{Introduction}

Entering the era of Information and Communication Technology (ICT) as currently, the pattern of education adopted in Indonesia begins to face some changes since the development of its. The need for ICTs in education is currently felt to be very significant and aims to improve anticipated standard of education. One of the main activities of the whole education process is
English language learning. The utilization of ICT, especially the internet as a medium of learning is an innovation in education at this time. Through ICT, we can increase the quality of learning, especially learning the English language, by opening up access to knowledge and information technology widely in the process of organizing quality and enjoyable English language learning. One of the English language learning programs that utilize the internet is the 
Distance Learning program. The innovation of this program also encourages educational institutions to provide educational services by utilizing the internet (Ismail, I., Elihami, E., \& Mustakim, M., 2019) which is also supported by the ability of the people now who are starting to depend on ICT.

The implementation of the Distance Learning program is currently not only implemented in colleges and formal schools. Non-formal schools have also organized a home-school distance education program. Parents are increasing demand for homeschooling to provide their children with education (Ismail, I., Busa, Y., \& Tini, T., 2018). Distance Learning programs are organizing one program and is widely known by the public is Homeschooling Kak Seto or commonly called HSKS. However, now homeschooling has developed in several areas in Indonesia. One of them is Homeschooling in South Sulawesi province, precisely in Makassar city. One of the homeschooling that is much in demand by many people in Makassar city and outside Makassar city is the homeschooling "Primagama Course Place".

English language learning assistance at "Primagama Course Place" is divided into three, namely Community Visit (visit to "Primagama Course Place"), Home Visit (mentoring at home), and Distance Learning (distance learning with an agreement on activities from school). All activities carried out at "Primagama Course Place" are the result of the agreement of parents to make individual student programs as partners of "Primagama Course Place". Likewise, with the form of English language learning assistance that was held "Primagama Course Place" namely Distance Learning program. "Primagama Course Place" as homeschooling not only provides direct English language learning assistance service directly but also provides English language learning services for students using indirect service. The success concept of this program is also supported by the process of managing or utilizing all educational resources. Therefore, one effort achieves quality English language learning, "Primagama
Course Place" must manage the Distance Learning program optimally. Therefore, the writer is interested in researching "Primagama Course Place" to find out how Distance Learning program management starts from planning until evaluation processes.

\section{Method}

The research employed a qualitative approach to investigate, understand and describe a research topic in terms and vocabulary in a concise manner (Moleong, 2019: 6-9). The type of this research used a case study that aims to review and describe the management of the Distance Learning program in "Primagama Course Place" homeschooling of Makassar City, South Sulawesi. The writer was a key instrument because the writer was the only data collector and played the role of an observer to know the conditions and get information directly at the "Primagama Course Place" Makassar City, South Sulawesi. The location of this research was the "Primagama Course Place" homeschooling located on Domba Street No.42, Maricaya, Makassar City, South Sulawesi, and postal code 90142.

The Sources of data in this research were the results of interviews, observations, and documentation. The object of the interview, observation, and documentation was the head of this homeschooling "Primagama Course Place", parents of students this homeschooling, children, and adolescents who are students of homeschooling, and teachers of this homeschooling. Data sources from this research were recorded through written noted or through audio recorders, while documents from this research could be in the form of photographs or official files. The writer conducted data analysis under what was stated by Miles (2018: 246), namely data reduction, data presentation, and concluding. Checking the validity of the data from this research was done through (1) data credibility by triangulation, member checking, increasing persistence, and adequacy of references; (2) transferability 
was done by making a report on the results of research with a detailed, clear, and systematic description, (3) dependence was done by auditing the research process conducted by the researcher independently, and (4) conformability was done carry out research from the beginning until the end.

\section{Results and Discussions}

\section{Results}

The activities of the Distance Learning program began by providing learning resources for learning the English language, namely online learning programs (Zenius, ZOOM, and LMS), worksheets, and other textbooks provided by parents. "Primagama Course Place" works closely with Zenius to provide Standard English language learning materials under the curriculum set by the Government. Next was to provide various information and communication technology devices (online facilities such as ZOOM and LMS)) which were vital needs of this Distance Learning program. The planning process before students (children and adolescents) decided on the Distance Learning program was carried out with the school choosing the curriculum to be adopted. Then the school together with parents rearranged the ideal curriculum to be applied for students (children and adolescents) while still referring to the curriculum set by the school following the curriculum of the education department. Then the school annually made academic programs and provided academic programs for parents as a benchmark in designed or arranged English language learning schedules. Learning schedules were made by parents and students (children and adolescents) then agreed with the school. In this planning activity, schools also pay attention to the commitment of parents before decided to join the "Primagama Course Place". The school entered into an agreement process in advance to find out how far the commitment and seriousness of parents to implement the Distance Learning program at 'Primagama Course Place. The agreement process was carried out by schools by way of interviewed, discussed, or shared with parents about this Distance Learning program.

The Distance Learning Program was implemented independently by students (children and adolescents) or there were additional teachers in the English language learning process. The English language learning process was carried out according to a self-made learning schedule. The implementation phase of English language learning consisted of: accessed online programs from Zenius, studied the material contained in Zenius in the form of descriptive and video, worked on questions, and immediately had discussions, worked on worksheets from school, and done assignments, and took examinations scheduled for school. Some assignments must be reported and collected as a result of learning the English language in the form of a portfolio for one semester. Daily English language learning activities utilized the internet to access online programs that had been provided by schools. In the Distance Learning program, communication was established between students (children and adolescents), parents, and schools through several social networks. This was due to a large distance between students (children and adolescents) with schools that did not allow for face-to-face meetings every day. So far, the school had been maintaining communication with students (children and adolescents) as well as parents to support English language learning activities and provided some information from the school. This was done because through good communication between school and parents and students (children and adolescents), the school could know the development of student learning (children and adolescents) despite the distance.

Supervision of the Distance Learning program at "Primagama Course Place" was carried out to monitor and oversee the implementation of English language learning activities carried out by students (children and adolescents). This supervision was carried out by the parents themselves and 
the school. Parental supervision was carried out daily by monitoring every student's English language learning activity (children and adolescents) at home. This was because parents were the ones in charge who must always supervise children's English language learning activities while at home. Whereas supervision by the school was carried out by giving daily journals. The daily journal must be filled out by students (children and adolescents) every day and signed by parents. After that, the journal must be reported to the school as proof that students (children and adolescents) really did carry out English learning activities. This Distance Learning program supervision activity "Primagama Course Place" focused more on the implementation of English language learning activities by students (children and adolescents) independently at home.

Evaluation of the Distance Learning program at "Primagama Course Place" included: program evaluation and evaluation of students' English language learning outcomes (children and adolescents). Program evaluation was carried out by a special team whose members each had the expertise or skills by the existing skills in learning the English language. In this Distance Learning program, there were team members who had expertise in the IT or information technology fields. Program evaluation conducted by "Primagama Course Place" was to follow the development of an online English language learning program

\section{Discussions}

Under the concept of the Distance Learning program in UU Number 20 of 2003 about the National Education System stated the Distance Learning program was an education where students (children and adolescents) were separated from the teacher and learning used various learning resources through communication technology, information, and other media. The school and parents of students (children and young people) must provide several electronic devices, networks, and learning resources that were used to access English learning. Some needs that were prepared before implemented the Distance Learning program were learning resources, electronic devices, and network devices that support the Distance Learning program. Learning resources came from online learning programs from Zenius in which there were raw materials that had been prepared by Zenius by the established curriculum. Electronic equipment that must be owned by students and schools was a Personal Computer (PC) or laptop and wireless network in the form of Wifi or other internet data packages.

The next plan was to establish a curriculum. The curriculum at "Primagama Course Place" referred to the 2013 curriculum under the provisions of the Makassar City Education Office. But the implementation or application was not the same as other formal schools. "Primagama Course Place" applied an ideal curriculum tailored to the needs of students (children and adolescents), this was done because each child and adolescents had their characteristics and the learning needs of students (children and adolescents) with each other could not be compared. Asmanai (2019: 135-145) emphasized the curriculum in homeschooling children and adolescents who would be subject to curriculum so that in the end the curriculum would adjust to children and adolescents. This could be seen in making the schedule of teaching English learning materials independently by students, parents, and agreed with the school. "Primagama Course Place" did not use the same lesson plan for all students (children and adolescents) as implemented in formal schools. Every schedule of English learning material that was made must be by the academic program that had been designed by the school in one year. Thus, students (children and adolescents) still had to adjust the schedule of their learning material with the school's academic program to take part in the activities and examinations held by "Primagama Course Place". 
The very important thing before running English learning in "Primagama Course Place" was the commitment of parents and students (children and adolescents). This commitment was needed to facilitate the learning process with the Distance Learning program because English language learning was done independently at home and parents had a very important role in supporting English learning of children and young people at home. This was supported by an explanation of homeschooling as informal education in UU Number 20 of 2003 concerning the National Education System "informal education activities carried out by families and the environment in the form of independent learning activities". In this case, to see how committed parents and students were before choosing the Distance Learning program at "Primagama Course Place", as a homeschooling school, the agreement process was done first. This agreement was carried out by the school in the form of interviews, discussions, and sharing with parents and students (children and adolescents) about the English learning program that students would take. "Primagama Course Place" would provide information in advance about the Distance Learning Program that was held so that parents and students (children and adolescents) got a picture of the learning to be carried out. If parents and students (children and adolescents) were determined to join the Distance Learning program at "Primagama Course Place" then they could register which could be done online or came directly to the school.

The implementation of the Distance Learning program at "Primagama Course Place" was carried out according to the schedule that had been made by students (children and adolescents) and independently in the homes of students (children and adolescents) respectively. English language learning activities carried out at home because "Primagama Course Place" was one of the types of homeschooling, according to the opinion of Adilistiono (2018: 34) that: "homeschooling was a system of education or learning English which was held at home as an alternative school that places children and adolescents as subjects with an approach at home ". So, each Distance Learning program activity was carried out at the home of each student (children and adolescents) without having to come to a school like a conventional school.

Some of the advantages of the Distance Learning program revealed by Rusman (2018: 271) namely: (1) it allowed anyone anywhere and at any time to learn anything; (2) learners could learn English teaching materials according to their characteristics; (3) the ability to make links; (4) very potential as a source of learning; (5) could encourage learners to be more activated and independent; (6) provided additional English language learning resources; (7) provided search engines to find the information they need; and (8) the contents of English subject matter could be updated easily. This could be seen in the implementation of the Distance Learning program. Students (children and adolescents) could freely access the Zenius online English language learning program in which English learning material, video tutorials, questions, and discussion were included. Students learned through Zenius as they wish because there was not a time limit.

The implementation of other English learning was by doing worksheets and independent assignments from school. All students (children and adolescents) must collect all assignments in one semester as a result of portfolio learning. All English learning activities were carried out independently and flexibly by students (children and adolescents) by accessing online programs and learning English from other learning resources. In this case, the Distance Learning program which was one of the programs of the "Primagama Course Place" homeschooling was included in the category of Self-directed Learning, where students (children and adolescents) carried out English language learning independently by accessing a variety of English language 
learning materials or materials that were had been provided. There was no instructor or a specific time for discussion among fellow students (children and adolescents) other. Each student (children and adolescents) undertook the process of learning English according to their needed (Widhiartha, 2019: 5).

The implementation of the Distance Learning program required good communication between students, parents, and schools due to the long distance and it was not possible between students (children and adolescents), parents, and the school can face to face continuously. Communication between students (children and adolescents) with the school was done virtually or cyberspace. The media used were several social media namely: Facebook, WhatsApp, and Skype. Whereas parents and schools mostly consulted, discussed, and shared about the development of English language learning of their children and adolescents during the Distance Learning program and the continuation of student education (children and adolescents) after graduation and also consulted with the school. Communication between parents and school was done via telephone, social media, and face to face. This communication must be established well between the school, parents, and students (children and adolescents) to align the desired between the school and students (children and adolescents) and parents as implementers so that educational goals could be achieved according to a plan that had been jointly designed. Through good communication between the three parties, namely: schools, students (children and adolescents), and parents, the development of students' English learning could be seen to know the extent of educational goals that had been achieved (Asmani, 2020: 161).

Supervision of the Distance Learning program at the "Primagama Course place" was conducted to monitor and oversee the implementation of English language learning activities carried out by students (children and adolescents). Supervision activities carried out by the school and parents of students (children and adolescents) themselves because the English language learning process was done independently at home. Supervision from the school was through a daily journal that must be reported to the school. Students (children and adolescents) must write what they learned both through Zenius online programs, worksheets, and other English learning resources. To avoid dishonesty of every student (children and adolescents), in the daily journal that must be reported to the school must be accompanied by the signature of the student's parents (children and adolescents) as proof that they really carried out learning activities in English language learning. The role of parents in the Distance Learning program was very important because learning the English language was done alone at home, so parents also supported the process of learning the English language to remain conducive and achieved better English language learning outcomes. This was because parents were the ones in charge who must always supervise the learning activities of the English language of their children and their adolescents while at home. In accordance with the opinion of Mayasari (2018: 8): "homeschooling, in general, was an educational model in which families choose to take responsibility for their own children's education and adolescence by using the home as the basis of education". So, parents had a very important role to support and oversee the implementation of the Distance Learning program which was carried out independently by children and adolescents at home.

The evaluation carried out by "Primagama Course Place" on the Distance Learning program consisted of an evaluation of the online program and an evaluation of students' English learning outcomes. This was by the concept of evaluating the Distance Learning program according to Zhuang (2020: 31) as followed. Level 1, an evaluation that aims to measure student satisfaction in terms of interaction and appearance of the E-learning program. Level 2 , was the process of measuring the results 
of learning English, whether students could absorb the material well. Level 2 evaluations must focus on measuring the extent to which the learning objectives of English were achieved and carried out after the English language learning processed ends to see whether students' knowledge of English increased. A simple example of level 2 evaluation was an exam conducted by an educational institution. Level 3 , was a process of measuring changes in behavior and knowledge of students. This evaluation was the most direct in measuring the effectiveness of learning the English language to increase the quality of English language learning of students. Level 4, was an evaluation that determined whether the E-learning program provided tangible results and was related to the goals of the organization or school. The results of this level 4 evaluation would be a contribution to the organization or school in achieving Elearning goals.

Furthermore, evaluations at levels 2 to 4 were conducted by the "Primagama course place" in the form of evaluations of student learning outcomes while participating in the Distance Learning program. The form of the evaluation carried out was through daily assignments, daily tests, midterm, final exam, practical work, and the National Examination. The assessment system was carried out by schools by way of recapitulated all the results of assignments, daily tests, practicum, midterm, and final exams. All grades of students' English learning outcomes (children and adolescents) were recapitulated in their entirety by using report cards. Report cards given to students (children and adolescents) consisted of insert report cards for UTS and semester reports for UAS. In seeing the extent of student learning outcomes (children and adolescents), "Primagama course place" provided KKM (Minimum completeness criteria). The KKM must be fulfilled by students (children and adolescents) in each grade of the assignments and examinations carried out. Conversely, if students (children and adolescents) did not meet the KKM, then the school provides additional tasks to fulfill it. Evaluation of student learning outcomes (children and adolescents) through the Distance Learning program of the Primagama course place homeschooling in the final stage was through the National Examination. The National Examination in homeschooling was through the National Education Equivalency Examination (UNPK) Package A (SD), Package B (SMP), and Package C (SMA). One effort to achieve the legality of homeschooling graduates was to follow the UNPK as revealed by Asmani (2020: 92): "homeschooling activities needed to be reported to the local Education Office so that homeschooling participants get an official diploma from the government. For primary school diplomas were Package A, Package B Middle, and Package C. High school the examination system was through a national exam. "This means that if students (children and adolescents) wanted to get an official diploma from the government, they must follow the UNPK Package A, B, and C.

Based on the research findings, in the implementation of the Distance Learning program there were several problems, included: 1) power outages when accessing online English learning programs, 2) poor internet network, 3) parents and students (children and adolescents) uncertain commitment, 4) children and adolescents who were slow learning English, and 5) children and adolescents who were not consistent with their English language learning schedule. Some of these problems as expressed by Rusman (2020: 271), namely: "access to attend learning often occurs problems for learners." In this case, power outages and poor internet networks often occur because the Distance Learning program itself utilized electronic media, information technology, and communication. Thus, the school had anticipated this problem from the start by giving notice to students (children and adolescents) to immediately confirm it to school. Thus, the English learning schedule could be adjusted again. While bad networks were overcome by using internet packages that were indeed appropriate for the 
conditions of the area or region of the student's residence (children and adolescents). Another problem was the commitment of parents and students (children and adolescents) themselves. Sometimes parents did not play an active role in guarding the learning of their children and adolescents while at home. While the Distance Learning program was carried out independently by students (children and adolescents) while at home and required responsibility and support from parents.

Efforts made by "Primagama Course Place" to overcome this problem were by continuing to coordinate between school and parents regarding agreements that had been made before, so parents and students (children and adolescents) must continue to learn according to agreements made so could continue the Distance Learning program. Besides, sometimes students (children and adolescents) were not in the mood and did not want to learn English according to the English language learning schedule they had made. This was overcome by the way the school and parents provided confirmation or consequences that must be done by students (children and adolescents) who did not want to be consistent. This effort aims to control learning activities so that they continued to run according to plans that had been made and still achieve the educational goals set by the school. Furthermore, the problem also faced by "Primagama Course Place" was with students (children and adolescents) who were slow in learning. Students (children and adolescents) had difficulty understanding learning materials independently, so schools must overcome this by providing teacher assistants to help students (children and adolescents) in their learning activities at home.

\section{Conclusions}

Planning for the Distance Learning program in "Primagama Course Place" consists of providing online English learning programs from Zenius, LKS, and other
English language learning resources provided by parents. Next is to provide electronic devices and networks in the form of PCs, laptops, Smartphones, Wifi, and other data packages. Then the determination of the curriculum by the Ministry of Education the school makes an academic program for one year as a benchmark in preparing English language learning schedules. English class schedules are made independently by students (children and adolescents) with parents and agreed with the school. In this planning activity, the school is very concerned about the commitment of parents before deciding to join the Distance Learning program. So that the school carries out the agreement process first employing discussion, consultation, and sharing programs with parents. After that, parents register online or come to school.

The Distance Learning program is carried out by students (children and adolescents) independently or there are additional teachers in English language subjects and according to a schedule that has been made. The implementation stage is by accessing Zenius, studying material and videos, working on questions, and immediately having a discussion. Doing worksheets, assignments, and examinations scheduled for school. Communication is established between students (children and adolescents), parents, and schools through several social media.

Monitoring of Distance Learning programs is carried out to monitor and oversee the implementation of English language learning activities. Supervision from the school through a daily journal that must be filled every day and reported. Whereas supervision by parents is carried out daily by monitoring every English language learning activity of children and adolescents because learning English is carried out independently by children and adolescents at their home.

Evaluation of the Distance Learning program consists of program evaluation and evaluation of English language learning outcomes. Evaluation of the Distance Learning program is carried out by a special 
team in monitoring innovations from Zenius online English language learning programs and communication media. Evaluation of learning outcomes in the English language is done in the form of giving daily assignments, UH, UTS, UAS, and UNPK. The results of students' English language learning (children and adolescents) are recapitulated in the form of the values contained in the report card. Problems in the Distance Learning program consist of: (1) power outages, (2) bad internet network, (3) parents and students (children and adolescents) who are not committed, (4) children and young people are slow in learning English, and (5) children and adolescents are not consistent with their lesson schedules. Furthermore, the solution for problems carried out by the school include: (1) confirmation to school and can change the time of English language lessons, (2) changing the internet network by the region, (3) there is a teacher/tutor who helps students (children and adolescents) learn, (4) ongoing coordination with parents and students (children and adolescents), and (5) affirmation and consequences for students (children and adolescents).

\section{Implication}

Based on the conclusion, this research provides advice to several parties including: (1) Head of the Makassar City Education Office in South Sulawesi province, it is hoped that more collaboration with "Primagama Course Place" in developing Distance Learning programs, (2) Head of "Primagama Course Place "In order to always provide more innovative and varied English learning programs support students (children and adolescents) to study English language learning, (3) parents always monitor and support English language learning activities of their children and adolescents, (4) Head of Department and Lecturer of English education program at the University of Muhammadiyah Enrekang to provide more knowledge about the management of English language learning in formal, nonformal, and informal education both in theory and practice, and (5) other writers so that it can be used as material ref new dimension and can continue this research by examining the development of the Distance Learning program "Primagama Course Place".

\section{References}

1. Adilistiono. 2018. Homeschooling sebagai Alternatif Pendidikan. Ragam Jurnal Pengembangan Humniora, (Online), $10 \quad$ (1):34-38, (http://www.polines. ac.id/ragam/i n d ex_file s / jurnal rag a m / paper_4\%20apr_2010.pdf), diakses 7 Maret 2017.

2. Asmani. 2020. Buku Pintar Homeschooling. (Syahriyanti, E. Ed.). Yogyakarta: Flash Books. 135-145

3. Ismail, I., Elihami, E., \& Mustakim, M. (2019). Students' Perceptions of the Benefits of Mobile Polling Technology in Teaching and Learning in College: Implications of Students' Participation and Academic Performance. Jurnal Pendidikan Progresif, 9(1), 89-104. Retrieved from http://jurnal.fkip.unila.ac.id/index.ph $\mathrm{p} / \mathrm{ipp} /$ article/view/17871

4. Ismail, I., Busa, Y., \& Tini, T. (2018). Parental involvement in fostering the character of children's discipline at elementary school. Jurnal Pendidikan Progresif, 8(2), 53-67.

5. Mayasari. 2018. Manajemen Pembelajaran Homeschooling. Skripsi tidak diterbitkan. Malang: Fakultas Ilmu Pendidikan. Universitas Negeri Malang.

6. Moleong. 2019. Metodologi Penelitian Kualitatif. Bandung: PT Remaja Rosdakarya. 6-9

7. Rusman. 2020. Pembelajaran Bahasa Inggris Berbasis Teknologi Informasi dan Komunikasi: Mengembangkan Profesionalitas Guru Bahasa Inggris. Jakarta: Rajawali Pers. 271

8. Sugiyono. 2020. Metode Penelitian Kuantitatif, Kualitatif, dan $R$ \& D. Bandung: Alfabeta. Undang-Undang 
Republik Indonesia Nomor 20 Tahun 2003 tentang Sistem Pendidikan Nasional. 2019: Sinar Grafika.

9. Widhiartha. 2019. Memahami Lebih Lanjut tentang E-Learning, (Online), (http:// ilmukomputer.org/wpcontent/uploads/2008/07/widhiarth a_elear ning.pdf), diakses 27 Februari 2018. 5

10. Zhuang. 2020. E-Learning: Konsep \& Aplikasi. (Sudiyarto, Ed.). Yogyakarta: Penerbit Andi. 31

11. Akkoyunlu, B., \&Soylu, M. Y. 2020. A Study of Student's Perceptions in a Blended Learning Environment Based on Different Learning Styles. Educational Technology \& Society, 4(1), 183.

12. Badawi, M. F. 2018. Using Blended Learning for Enhanced EFL Prospective Teachers' Pedagogical Knowledge and Performance. Conference Paper: Learning \& Language - The spirit of the Age. Cairo: Ain Shams University. 15

13. Brew, L. S. 2019. The Role of Student Feedback in Evaluating and Revising Blended Learning Course. Internet and Higher Education, 13, 98.

14. Cabrera, M. P. \& Bazo, P. 2019. Teaching the Four Skills in the Primary EFL Classroom. The Internet TESL Journal, Vol. VIII, No. 3, Januari 2019.

Dari http://iteslj.org/Techniques/BazoFourSkills.html

15. Demirci, N. 2019. Web-Based vs. Paper-Based Homework to Evaluate Students' Performance in Introductory Physics Courses and Students' Perceptions: Two Years' Experience. International Journal on E-Learning, 9(1), 27.

16. Hameed, S., Badii, A. \& Cullen, A.J.2019.Effective E-Learning Integration with Traditional Learning in a Blended Learning Environment. European and Mediterranean Conference on Information System. 3.

17. Harmer, Jeremy. 2018. The practice of English Language Teaching.
18. Hasan, H., \& Ismail, I. (2020). The Effectiveness Material Based Stories in Improving Students Reading Comprehension. MAJESTY JOURNAL, 2(1), 40-46. https://doi.org/10.33487/majesty.v 2i1.332

19. Elihami, E., \& Ismail, I. (2017). Increasing Students' Reading Comprehension Through Cognitive Strategis of Senior High School of Sidenreng Rappang Regency. Edumaspul - Jurnal Pendidikan, 1(2), 61-70.

https://doi.org/10.33487/edumasp ul.v1i2.41

20. Ismail, I., \& Tini. (2020). The Effect of formative assessment on students' grades in learning English. Maspul Journal of English Studies (Majesty Journal), 2(1), 20-30. https://doi.org/10.33487/majesty.v $2 \mathrm{i} 1.313$

21. Ismail, Samad, I. S., Busa, Y., Mustakim, \& Elihami. (2020). Mengajar di Saat Pandemi COVID-19: Transisi ke pembelajaran Online setelah Menghabiskan Waktu Bertahun-tahun di Kelas. April.

22. Longman. Lawson, Karen. 2018. The Importance of Reading. Growing Greatness: Series of Article to Cultivate Truly Outstanding leaders.

23. Lawson Consulting Group, Inc. Marsh, Debra. 2019. Blended learning: Creating Learning Opportunities for Language Learners. New York: Cambridge University Press.

24. McCarthy, M. A., \& Murphy, E. A. 2018. Blended learning: Beyond initial uses to helping to solve real-world academic problems. Journal of College Education \& Learning, 7(6), 67.

25. Mega, I. (2020). Students' Perception of Digital Literacy Competence as Learning Sources. MAJESTY JOURNAL, 2(1), 47-53. https://doi.org/10.33487/majesty.v 2i1.351

26. Musdalifah, M. (2019). The Comparison of Mind Mapping and 
Semantic Mapping to Enhance the Reading Comprehension. MAJESTY JOURNAL, 1(2), 1-9. https://doi.org/10.33487/majesty.v $\underline{1 \mathrm{i} 2.117}$

27. Syarif, Izuddin. (2018). Pengarug Model Blended Learning terhadap Motivasi dan Prestasi Belajar Siswa SMK. Jurnal Pendidikan Vokasi, Vol 2, Nomor 2, Juni 2018. 238
28. Sjukur, Sulihin B. (2020). Pengaruh Blended learning terhadap Motivasi Belajar dan hasil belajar Siswa Tingkat SMK. Jurnal Pendidikan Vokasi, Vol 2, Nomor 3, Januari 2010.

29. Vaughan, N . (2019). Perspective on Blended Learning in Higher Education. International Journal on ELearning, 6 (1), 81-94 